\title{
La violencia sexual en conflictos armados bajo el Derecho Penal y el Derecho Internacional ${ }^{* *}$
}

\author{
Sexual violence in armed conflicts under Criminal Law and International Law
}

\author{
Josefina Miró Quesada Gayoso(**) \\ Perú - Pontificia Universidad Católica del Perú
}

\begin{abstract}
"Golpes en el rostro, en el abdomen, las piernas estiradas hasta el infinito. Serrana hija de puta. Hacen fila para disfrutar su parte del espectáculo. Ningún orificio queda libre en esta danza sangrienta. India piojosa. Solo dolor en este bulto como un nudo apretado al cual no se le encuentra solución. ¿Cuánto tiempo más puede durar esto? Que pare de una vez. Paren, paren, paren. Siga usted, soldadito, complete el trabajo, complételo. ¿Hasta cuándo pueden seguir haciéndolo? Dale con fuerza que estas cholas aguantan todo".

C. Salazar $(2016)^{(* * *)}\left(^{(* * *)}\right.$
\end{abstract}

\begin{abstract}
Resumen: El presente artículo estudia la violencia sexual como arma de guerra perpetrada en contextos de conflicto armado y analiza, a partir del caso peruano, el marco jurídico aplicable para perseguir y sancionar tales hechos durante el conflicto armado interno entre 1980-2000 a la luz del derecho penal nacional e internacional y el derecho internacional de los derechos humanos. De acuerdo con el Informe Final de la Comisión de la Verdad y Reconciliación (CVR), en ciertas zonas, esta violencia calificó como crímenes de lesa humanidad y crímenes de guerra. Judicializarlos solo bajo la ley penal aplicable al momento de los hechos resulta insuficiente de cara a las obligaciones del Estado de perseguir y sancionar este fenómeno. Se sugiere así, la aplicación de estándares internacionales que le dan contenido al tipo penal, así como una interpretación alternativa del principio de legalidad, que permita aprehender el real desvalor sociojurídico de estos actos.
\end{abstract}

Palabras claves: Violencia Sexual - Conflicto Armado Interno - Perú - Manta y Vilca - Derecho Penal - Sistema Romano

\begin{abstract}
This article studies sexual violence as a weapon of war perpetrated in contexts of armed conflicts and analyzes, based on the Peruvian case, the applicable legal framework to prosecute and punish such acts during the non international armed conflict between 1980-2000 under the light of national and international criminal law and international human rights law. According to the Final Report of the Truth and Reconciliation Comission, in certain areas, this violence qualified as crimes against humanity and war crimes. Judging these only under the criminal statute applicable at
\end{abstract}

(*) Nota del Editor: este artículo fue recibido el 21 de octubre de 2019 y su publicación fue aprobada el 7 de noviembre de 2019.

${ }^{* *}$ ) Abogada por la Pontificia Universidad Católica del Perú. Periodista e investigadora del Grupo de Investigación sobre Protección Internacional de los Derechos de las Personas y los Pueblos (PRIDEP) y el Grupo de Investigación de Derecho Penal y Criminología (GRIPEC). Adjunta de docencia en cursos de derecho penal, criminología y derecho internacional. Contacto: josefina.miro.quesada@ gmail.com

${ }^{* * *}$ Salazar, C. (2016). La sangre de la aurora (2da ed.). Lima: Animal de Invierno.

${ }^{* * * *}$ La novela narra la historia de violencia de tres mujeres durante el conflicto armado interno en Perú (1980-2000). Las vivencias de una fotógrafa lesbiana y limeña que viaja a Ayacucho, de una militante senderista presa y una campesina indígena, a pesar de las diferencias sociales y políticas que las separan, se entrelazan como una trenza para graficar qué las une: cuerpos sexualizados, castigados, dominados usados como botín de guerra por varones en abuso de su poder (2016, pág. 75). 
the time of the events is insufficient for the State's international obligations to prosecute and punish this phenomenon. Thus, it is suggested, the use of international standards that gives content to the national statute, as well as an alternative interpretation of the principle of legality that allows apprehending its real socio-legal devaluation.

Keywords: Sexual Violence - Internal Armed Conflict - Peru Manta y Vilca - Criminal Law - Civil Law

\section{Introduc ción}

La violencia sexual en conflictos armados ha sido un fenómeno invisibilizado a lo largo de la historia. Por mucho tiempo, se creyó que era un efecto colateral de la guerra (Segato, 2016, pág. 160), un costo que había que tolerar, dado el desenfreno inhumano de estos escenarios. Sucedió así con los juicios de Núremberg, donde los sufrimientos de miles y miles de mujeres de todas las edades y nacionalidades fueron ignorados, a pesar de la evidencia que recibió el tribunal sobre las violaciones masivas cometidas por el Ejército Alemán. En ninguna de las 179 páginas de la sentencia final de Núremberg, figuró la palabra violación.

En Tokio, si bien los cargos de violación fueron reconocidos por el Tribunal Penal Militar Internacional para el Lejano Oriente, donde cerca de 20 mil mujeres fueron víctimas de violación sexual en la masacre de Nankín y unas 200 mil fueron usadas como 'confortadoras' para ejercer la prostitución forzada por el Ejército Imperial Japonés, estos fueron procesados de manera muy limitada. Refiriéndose a las violaciones masivas en el conflicto armado en la ex Yugoslavia, a partir de 1991, Odio Benito sostiene que la violación en tiempos de guerra "no es más que un capítulo que se agrega al sufrimiento de las mujeres a través de los siglos" (2001, pág. 267). En el Perú, más de treinta años después de perpetrados los hechos de violencia sexual durante el Conflicto Armado No Internacional (CANI) entre 1980 y 2000, la justicia aún no condena a los responsables de la violencia sexual ejercida en el marco de una política sistemática del Estado, tal como lo reconoció la CVR. ¿Por qué sucede esto y cómo revertirlo? En la actualidad, el único caso en etapa de juicio oral es el de Manta y Vilca y, en cuanto a los demás, casi todos permanecen sumidos en el olvido.

Este artículo tiene como punto de partida esta realidad con el propósito de entenderla y ofrecer herramientas jurídicas, incluida una alternativa a la interpretación tradicional del principio de legalidad que permita judicializar estos hechos de conformidad con la gravedad que representan, a fin de superar los obstáculos que aparecen por el paso del tiempo. Para ello, se analiza primero la dimensión y las características del fenómeno a partir de las conclusiones del Informe Final de la CVR, bajo una perspectiva de género que visibiliza las razones que subyacen a este tipo de violencia, y explica el uso de la violencia sexual como táctica militar. Luego, se abordan las limitaciones principales de las leyes vigentes al momento de los hechos y la investigación de estos casos para finalmente, ofrecer insumos que permitan interpretar adecuadamente los delitos sexuales, acorde a su naturaleza, identificados durante ese período bajo estándares del derecho penal internacional (DPI), el derecho internacional de los derechos humanos (DIDH) y la jurisprudencia del derecho penal nacional (DP).

\section{EI registro de la Comisión de la Verdad y la Reconciliación (CVR)}

Tras dos años de trabajo y cerca de 17 mil testimonios recogidos, el 28 de agosto de 2003, los miembros de la CVR presentaron su Informe Final, en el cual detallan las causas y consecuencias del CANI en el Perú durante 1980 al 2000 entre las fuerzas armadas del Estado, y los grupos terroristas, el Partido Comunista del Perú-Sendero Luminoso (PCP-SL) y el Movimiento Revolucionario Túpac Amaru (MRTA). Casi 70 mil personas fallecieron o fueron desaparecidas, dentro de los cuales, tres de cada cuatro fueron campesina/os cuyo idioma materno no era el español. La CVR no tuvo, como parte de su mandato expreso, la tarea de investigar la violencia sexual durante el CANI en el Perú. Sin embargo, fue incluido dentro del concepto de "torturas y otras lesiones graves", así como de "crímenes y graves violaciones contra los derechos de las personas"(1). Se convirtió, así, en la primera comisión de la verdad en el mundo en incluir una perspectiva de género desde el inicio de su trabajo (Mantilla, 2006, pág. 324).

El análisis del impacto diferenciado de la guerra a partir de una perspectiva de género permitió visibilizar cómo la construcción social y cultural de atributos, prácticas,

(1) Artículo 3 del Decreto Supremo 065-2001-PCM. 
características asociadas a mujeres y hombres se constituyó en una fuente de relaciones desiguales de poder que incidió en la restricción desproporcional de determinados derechos de las primeros sobre los segundos. En el caso de la CVR, esta herramienta permitió identificar que a las mujeres se las atacaba no solo por su participación en enfrentamientos, sino por ser esposas o familiares de los actores del conflicto (Mantilla, 2006, pág. 346). A su vez, permitió identificar que la violación de derechos tenía secuelas más graves, en base al género al que pertenecía la víctima, como ocurría con el caso de las violaciones sexuales, donde si bien hombres y mujeres podían sufrir un acto de esa naturaleza, solo las mujeres resultaban embarazadas, destinadas a cargar con las consecuencias de una maternidad o un aborto forzado (Mantilla, 2006, pág. 347).

En el caso de las desapariciones forzadas, el enfoque de género logró identificar que la razón detrás del hecho de que las víctimas eran mayoritariamente hombres, era que ellos participaban del espacio público, siendo así, los actores perseguidos. Esta herramienta, además, obligó a las y los investigadores a preguntarse cómo la ausencia de estos varones afectó la vida de las mujeres que le rodeaban, a identificar los nuevos roles sociales que ellas debieron encarar para mantener y dar continuidad al hogar compartido, y a observar la salida al espacio público que tuvieron que enfrentar como resultado de la denuncia de violaciones a derechos humanos contra sus familiares. Sin esta mirada, no habría podido identificarse que la razón por la cual los hombres escapaban antes que las mujeres, haciéndolas más propensas a ser detenidas o sometidas a torturas y violación sexual, era que estas demoraban en recoger a los hijos y reclutar alimentos para sobrevivir, en su rol atribuido de madre-cuidadora del hogar (2006, pág. 347).

La aproximación de género informa "sobre las relaciones de poder y el ejercicio de la violencia en la vida privada y en el escenario público, y los modos en que los códigos de género se articulan con la discriminación y el racismo" (Henríquez Ayin \& Reynoso Rendón, 2006, pág. 37). El enfoque interseccional coadyuva, a su vez, a reconocer que la violencia que viven las mujeres está condicionada por ejes de subordinación que generan una mayor vulnerabilidad y discriminación en su contra, no solo por su género, sino por el origen étnico, clase, religión, las creencias, la salud, el estatus, opinión política, orientación sexual y otras identidades a las que pertenecen ${ }^{(2)}$.
Así lo comprueban las cifras del Informe Final que revela que las mujeres que sufrieron con mayor intensidad la violación sexual fueron las "peruanas más excluidas, y por lo tanto, desprotegidas" (CVR, 2003, pág. 26). En su mayoría, mujeres campesinas (36\%), quechuahablantes $(75 \%)$, de origen rural $(83 \%)$ o amas de casa (30\%). En relación a la edad, la mayoría fueron jóvenes, siendo la mayor incidencia en niñas a partir de los 11 años, aunque el registro da cuenta de mujeres mayoritariamente entre 10 a 29 años. La violencia sexual estuvo presente en 538 testimonios de la CVR, de los cuales 527 era contra mujeres y 11 contra hombres. Sin embargo, a setiembre de 2016, el Registro Único de Víctimas registraba a 4,540 mujeres víctimas de violación sexual, así como a 117 víctimas varones. De estos casos, 22 fueron objeto de investigación fiscal o proceso judicial, y solo el de María Magdalena Monteza Benavides (MMMB) recibió condena por secuestro agravado, pero no por violación sexual (Boesten, 2016, pág. 203).

Según la CVR, las violaciones sexuales fueron parte de una práctica "en algunos casos generalizada y en otros, sistemática" imputables a agentes estatales (83\%), y en menor medida, a integrantes de PC-SL y el MRTA $(11 \%)^{(3)}$. Así, fueron calificadas como crímenes de lesa humanidad (CVR, 2003, pág. 265). Para entonces, también se reconoció que la violencia sexual fue una transgresión de las normas mínimas de humanidad, con lo cual, constituía, además, un crimen de guerra, reconocido por los tribunales ad hoc para la ex Yugoslavia y Ruanda, así como por el Estatuto de Roma. Las resoluciones del Consejo de Seguridad lo reconocen así desde el $2000^{(4)}$. Igualmente, la Corte IDH lo reconoce al precisar que esta fue una práctica generalizada dentro de las fuerzas de seguridad basada en género, "pues afectó a las mujeres por el solo hecho de serlo"(5).

(2) Comité CEDAW. Recomendación General Nro. 28 relativa al artículo 2 de la Convención sobre la eliminación de todas las formas de discriminación contra la mujer. CEDAW/C/GC/28. 16 de diciembre de 2010, párrafo 18.

(3) El porcentaje residual (6\%) corresponde a la categoría no determinados y otros.

(4) Security Council agenda on women, peace and security, in particular resolutions 1325 (2000), 1820 (2008), 1888 (2009), 1889 (2009), 1960 (2010) and 2106 (2013).

(5) Corte IDH. Caso Espinoza Gonzáles Vs. Perú. Excepciones Preliminares, Fondo, Reparaciones y Costas. Sentencia de 20 de noviembre de 2014, párr. 225. 
Si uno compara la violación sexual con otros crímenes o violaciones graves a derechos humanos, verá que no está entre los más extendidas. Solo el $1.53 \%$ del total de casos registrados por la CVR lo fue. No obstante, la cifra es apenas una subrepresentación del fenómeno. La vergüenza, la culpa y el miedo que acompañan a las mujeres que reciben la condena de su familia y comunidad (Theidon, 2015, pág. 507), y el que ellas acudieran a las autoridades en condición de denunciante de violaciones a derechos humanos de terceros, no de víctimas directas, se encuentra detrás de esta explicación. Aunque la violencia sexual se manifiesta de distintos modos, la CVR solo contabilizó, en su base de datos, los casos de violación sexual y dejó a un lado la prostitución forzada, unión forzada, aborto forzado, servidumbre sexual, esterilizaciones forzadas y otras ${ }^{(6)}$. Como esta se ejerció en el marco de otras graves violaciones a derechos humanos, se priorizaron estos actos en el registro por sobre los de violencia sexual, lo que, consecuentemente, incrementó su invisibilización. Es muy probable así, que las mujeres víctimas de desaparición forzada, tortura o ejecuciones extrajudiciales hayan sido también víctimas de violencia sexual (CVR, 2003, pág. 275).

\section{La violación como 'arma de guerra'}

La violencia sexual en contextos de conflicto armado ha sido entendida históricamente como un arma de guerra. Esto, porque opera como una estrategia o un instrumento para combatir y ganarla. Se ha entendido, así, que abusar de las mujeres es una ofensa a los hombres del bando contrario (una afrenta a 'sus' mujeres). En palabras de Brownmiller (1975), "[l]os hombres de naciones conquistadas veían la violación de 'sus' mujeres como la última humillación". El mensaje para tales hombres, sostiene Dador Tozziani, es "violo a tu mujer, tu propiedad, te afrento a ti y el honor de tu familia', además de recordarles que han fallado en su rol de protección" (2007, pág. 19).

En el Perú, se usó como parte de la violencia pública masiva en incursiones a los pueblos y en la subordinación de estas comunidades. Los soldados eran sometidos a 'ritos de iniciación' donde se les exigía cometer tales actos para garantizar su lealtad y complicidad a la institución (Boesten, 2010, pág. 77). También, fue usado como método de tortura a modo de estrategia militar y como 'botín de guerra' -es decir, premio- donde las mujeres eran capturadas y regaladas no solo a los militares, sino a los miembros de Comités de Autodefensa (CAD), cómplices igualmente de la subordinación de la población civil. "Esta complicidad, a su vez, impone lealtad al Ejército y favorece la destrucción del tejido social existente de la población" (Boesten, 2010, pág. 78).

La idea de usar la violencia sexual como 'arma de guerra', según Boesten (2016), se origina en el pensamiento feminista que relaciona el significado simbólico de la violación con conceptos de 'nación' y 'etnicidad', donde las mujeres, dada su función reproductora, por omisión, condicionan el futuro de una nación. "Estas dinámicas se dieron especialmente en las guerras de la ex Yugoslavia y Ruanda, donde los cuerpos de las mujeres fueron explícita y sistemáticamente asaltados para destruir a un grupo culturalmente definido: bosniomusulmanes en partes de la ex Yugoslavia y tutsis en Ruanda", señala (pág. 270). Aunque el CANI en Perú no fue un conflicto étnico, sí tuvo un fuerte componente racial y étnico donde, en ciertos contextos, la violación fue facilitada por la idea de la otredad racial, esto es, la creencia arraigada de que las mujeres indígenas eran seres 'inferiores' (Boesten, 2016, pág. 270).

Según la autora, aunque se utilizó como tal, no es suficiente entender la violencia sexual bajo ese concepto. De ahí que sostenga que existen distintos regímenes de violación: como arma de guerra, como consumo y como violencia sexual invisibilizada. "Los militares, la policía y los comités de autodefensa campesina usaron la violencia sexual como medio para una variedad de objetivos, como satisfacción sexual, entretenimiento, intimidación, botín, y sumisión de comunidades enteras" (Boesten, 2016, pág. 270). Aunque inmerso en la violencia y el dominio físico, la violencia sexual no solo sirvió para fines estratégicos dirigidos desde arriba, sino que fue un evento sexual deseado y perseguido por los militares (Boesten, 2016, pág. 270).

La idea de consumo también se vincula a la de entretenimiento y espectáculo, y a la promoción de lazos masculinos. Testimonios dan cuenta que los soldados observaban

(6) Según la CVR, por violencia sexual se entiende la realización de un acto de naturaleza sexual contra una o más personas o cuando se hace que esa(s) personas realicen un acto de natural sexual: por la fuerza o mediante la amenaza de la fuerza o mediante coacción, como la causada por el temor a la violencia, la intimidación, la detención, la opresión psicológica o el abuso de poder, contra esa(s) personas u otra persona o aprovechando un entorno de coacción o la incapacidad de esa(s) personas de dar su libre consentimiento. Incluye diferentes modalidades y conductas afines como la prostitución forzada, la unión forzada, la esclavitud sexual, los abortos forzados, los embarazos forzados y la violación sexual, pág. 264-265. 
alegremente cómo otros violaban a mujeres fallecidas o moribundas (CVR, 2003; pág.342) no como una estrategia militar sino como parte del espectáculo, donde el consumo de sexo forzado y violento refuerza no solo la subordinación de las comunidades, sino las jerarquías entre los soldados. Finalmente, la autora habla de la violencia sexual invisible como aquella perpetrada por vecinos, conocidos, esposos; o la 'usada' por mujeres para intercambiar protección y/o información (aquí los linderos de lo que es consentimiento en contextos de opresión y coerción se desdibujan), y otros.

Así, podría sostenerse que la violencia sexual no solo sirvió para propósitos de ser un arma de guerra. No fue algo extraordinario, sino el resultado también de violencias exacerbadas y desigualdades de género, etnia, clase existentes en tiempos de paz, lo que permite hablar de un continuo de violencia. Los conflictos agravan las desigualdades existentes entre los géneros y aumentan el riesgo de las mujeres de ser víctima de distintas formas de violencia por razón de género, por parte de agentes estatales y no estatales ${ }^{(7)}$. Dicha agresión podía ser un instrumento de humillación y castigo para obtener confesiones de las víctimas -estrategia de guerra-, pero también podía ser la mera expresión del poder absoluto de los hombres sobre las mujeres ${ }^{(8)}$.

\section{La (in)‘justicia': décadas de impunidad}

La CVR contribuyó en materializar el derecho a la verdad de las víctimas y de la sociedad al informar sobre las causas del conflicto, pero nunca tuvo facultades jurisdiccionales para resolver los casos de violación de derechos. A pesar de ello, el impacto que tuvo en facilitar el acceso a la justicia de las víctimas fue esencial. Creó una Unidad de Investigaciones Especiales (UIE) que entregó al Ministerio Público 200 casos para ser investigados, en los cuales se señalaban presuntas responsabilidades penales. De estos, 73 casos fueron elegidos como los más representativos de las violaciones a derechos humanos perpetradas por el Estado, PCP-SL y MRTA. Ahí, se analizaron temas de autoría y participación, posibles barreras en las investigaciones como las leyes de prescripción, amnistía o juzgamiento de los hechos en el fuero común (Salazar Luzula, 2006, pág. 194). De estos casos, increíblemente se determinó que solo dos de violencia sexual tenían prueba suficiente (caso MMMB y Manta y Vilca) para ser presentados a la fiscalía en setiembre de 2003.

La evidencia entregada a la fiscalía y la documentación de testimonios no han sido, sin embargo, suficientes para lograr una condena del Poder Judicial que sancione de manera célere a los responsables de las masivas manifestaciones de violencia sexual contra un sinnúmero de mujeres mayoritariamente campesinas, durante el CANI. La CVR advirtió en su informe sobre la falta de investigación suficiente del fenómeno por parte de los operadores de justicia, insistiendo en que el deber de investigarlas es una obligación internacional del Estado de medios, o comportamiento por parte del Estado, no de resultados (CVR, 2003, pág. 380).

Para descartar o cerrar casos de violencia sexual, sin embargo, la judicatura invocó tres razones principales: i) definición del crimen, ii) falta de pruebas y iii) ausencia de perpetradores (Boesten, 2016, pág. 194). En lo que respecta a lo primero, los fiscales y jueces tendían a definir los casos de violación sexual como un crimen común, en vez de como un crimen de lesa humanidad. Esta calificación, dada la ausencia de implementación normativa de crímenes internacionales y una aproximación estricta del principio de legalidad, no solo, en palabras de Boesten, "descontextualiza el acto de una situación de violencia sistemática y terror, y anula los argumentos contextuales que pueden demostrar la probabilidad de la violencia sexual, tales como el marco temporal y el lugar", sino "automáticamente mina su validez judicial”, dadas las leyes de prescripción en el caso del delito de violación sexual vigente al momento de los hechos.

Esto tiene aún más sentido si al momento de ocurridos los actos de violencia, existía un marco legislativo nacional que favorecía la impunidad. Hasta 1997, el Código Penal (en adelante CP) de 1991 exoneraba al presunto agresor de una violación sexual si este ofrecía a la víctima casarse con él, supuestamente de forma voluntaria. En caso de una violación grupal, bastaba que uno lo hiciera para eximir de responsabilidad al resto. Muchos de los padres de las víctimas negociaban con los militares agresores para que sus hijas se

(7) Recomendación General No.30 sobre las mujeres en la prevención de conflictos y situaciones de conflicto y posteriores a conflicto, pág.14.

(8) Declaración rendida el 27 de marzo de 2014 ante fedatario público por Félix Reategui Carrillo (expediente de fondo, folios 921 y 926). Caso Espinoza Gonzáles vs. Perú. Excepciones Preliminares, Fondo, Reparaciones y Costas. Sentencia de 20 de noviembre de 2014. 
casaran con ellos, a cambio de que les 'restaurasen' el honor mancillado, bajo el entendimiento de que eso era lo que lesionaba la violación sexual.

A ello, se suma el hecho de que, aunque el CP de 1991 cambia el bien jurídico 'honor sexual' por 'libertad sexual', no modifica el que estos delitos dejen de ser de acción privada, con lo cual hasta 1997 dependían de la denuncia de la víctima para que se iniciara una investigación fiscal y permitía la conciliación con el agresor, fomentada en audiencia por un juez. El delito recogido en el CP de 1924, por su parte, no sancionaba los actos de violación contra varones porque se entendía que solo las mujeres podían ser violadas, y es que reconocer que un hombre podía ser víctima de violación sexual implicaba desvalorarlo socialmente (Dador Tozzini, 2007, pág. 25).

En el mejor de los casos, para investigar estos hechos se pudo optar por el método de la doble subsunción para sopesar el paso del tiempo, en virtud del cual, se utiliza de manera simultánea los tipos penales vigentes al momento de los hechos, sumado a una calificación internacional del hecho como crimen de lesa humanidad y/o crimen de guerra. Esta opción la utilizó la Corte Suprema en la condena contra el ex presidente Alberto Fujimori por la matanza de Barrios Altos y La Cantuta. Se entendió que solo así se respetaba el principio de legalidad estricta del artículo II del Título Preliminar del CP de 1991, que exige remitirse a la ley penal vigente al momento de los hechos, bajo las garantías de la ley previa, estricta, cierta y escrita, como así lo establece el Tribunal Constitucional(9), que ha señalado, además, que es un derecho subjetivo que protege ${ }^{(10)}$ a los individuos de los márgenes de actuación del Poder Legislativo al comunicar qué conductas estarán prohibidas, pero también del Poder Judicial, al determinar cuáles serán sancionadas.

\subsection{Los crímenes internacionales en Manta y Vilca}

El caso Manta y Vilca se remonta a la violencia sexual ejercida por militares entre 1984 y 1995 contra mujeres campesinas de los distritos de Manta y Vilca en Huancavelica, declarado en estado de emergencia por esos años. El control militar y político en dichas zonas derivó en vulneraciones de derechos contra los campesinos y campesinas, pero fueron mujeres las ultrajadas sexualmente bajo la sospecha de ser miembros o simpatizantes del PCP-SL. Esa era la estrategia para hacer que se autoinculparan o entregaran información de posibles terroristas. Las mujeres de Manta y Vilca estaban entre dos fuegos: convivían con el PCP-SL y eran castigadas por las Fuerzas Armadas (Salazar Luzula, 2006, pág. 197). Muchas quedaron embarazadas producto de la violación, con hijos que fueron registrados al nacer con el apellido del grado del padre o el apelativo (moroco, capitán, verde, militar), bajo el desconocimiento de quiénes eran los agresores. En Manta, por lo menos, hay 32 hijo/as no reconocidos (Wiesse et al., 2018, pág. 21).

Luego de casi seis años de investigación, el 25 de marzo de 2009, el Cuarto Juzgado Penal Supraprovincial de la Corte Suprema abrió instrucción contra diez ${ }^{(11)}$ miembros del Ejército por los delitos de violación sexual en agravio de M.A.E y otras mujeres en Manta y Vilca. En el auto, el juzgado calificó los hechos como actos de violación contra la libertad sexual y dado el contexto en el que se desarrollaron, como delitos contra la humanidad (Pérez-León Acevedo, 2009, pág. 14). Es decir, actos delictivos (como el asesinato, tortura, violación sexual, etc.), cometidos de manera generalizada (gran escala) o sistemática (cierto nivel de organización) contra la población civil.

Esta calificación permitió abrir una investigación que, de no haberse dado, habría hecho prescribir el delito. En total, son nueve mujeres denunciantes. Aunque la fiscalía pidió que los hechos fueran también calificados como actos de tortura, la Sala consideró que era una "clara confrontación con el principio de legalidad e irretroactividad de la ley penal"(12), pues el tipo penal se incorporó en 1998, pese a que tratados internacionales (artículo 5 de la CADH y el 7 del PIDCP) ya lo prohibían. El juicio oral sigue en curso, pero, debido a la tipificación penal interna, el marco de pena aplicable denota un desafío frente al desvalor sociojurídico de hechos calificados a nivel internacional como crímenes de lesa humanidad. De considerar eventualmente la responsabilidad penal de los acusados, los magistrados deberán resolver cómo superar esta atingente.

De cara a casos como este, el siguiente acápite busca, por ende, dar insumos para la

(9) Expág. N. 010-2002-Al/TC, párr. 46. / Expág. N. 08646-2005-PHC/TC, párr. 1.

(10) Tribunal Constitucional. Expág. 08886-2006-PHC/TC, fundamento 4.

(11) En la actualidad (2019), son 14 acusados en juicio oral.

(12) Cuarto Juzgado Penal Supraprovincial de Lima. 2009.“Auto apertorio de instrucción del caso de las mujeres violadas en las comunidades de Manta y Vilca", pág. 10. 
persecución penal de la violencia sexual en conflicto armado bajo el derecho penal, a la luz de estándares del DPI y el DIDH. Esta última fuente de derecho se integra al derecho nacional, conforme lo establece el artículo 55 de la Constitución, el artículo 3 y la Cuarta Disposición Final y Transitoria, al sostener que toda interpretación de la promoción y protección de los derechos fundamentales debe considerar lo establecido en las respectivas fuentes. El control de convencionalidad, por su parte, impone el deber a las juezas y jueces peruanos no solo de ejercer control difuso cuando identifican que una ley es contraria a la Constitución, sino cuando la misma contraviene la jurisprudencia de tribunales internacionales sobre derechos humanos, como la Corte IDH, donde no solo es vinculante la parte resolutiva, sino el desarrollo de la misma (la ratio decidenci) $)^{(13)}$.

\subsection{Derecho Penal Internacional (DPI)}

EI DPI se basa en fuentes del Derecho internacional, pero no deja de ser materialmente un derecho de naturaleza penal, capaz de sancionar y privar de libertad a un individuo responsable no solo de lesionar un bien jurídico, sino de colocarlo en una situación de riesgo prohibido. Para Ambos (2004), es el sistema penal de la comunidad internacional, el cual vincula los conceptos de aplicabilidad universal de las normas (propias del Derecho Internacional Público), y a la vez, los conceptos de responsabilidad penal individual (propios del derecho penal), de manera tal que "la conducta respectiva queda sujeta a una punibilidad internacional autónoma (principio de responsabilidad penal directa del individuo según el Derecho Internacional Público)" (pág. 47).

Los crímenes de lesa humanidad o crímenes de guerra, en tanto crímenes internacionales, son conductas contrarias a normas del DPI que ponen en riesgo los bienes jurídicos más trascendentales protegidos por el orden público internacional (Barboza, 1999, pág. 680), cuya comisión genera responsabilidad penal individual, incluso por encima del derecho interno (Principio II Núremberg). La violación sexual, bajo ciertas circunstancias, puede ser un crimen de lesa humanidad -si se dirige contra la población civil, si el ataque es sistemático o generalizado y si se cometió como parte de una política de Estado o de una organización- o un crimen de guerra si es una grave transgresión al $\mathrm{DIH}$, conexo a un contexto de conflicto armado.

Así lo estableció el TPIY en el caso Furundzija en diciembre de 1998, cuando demostró que la prohibición de la violencia sexual en conflictos armados había evolucionado hasta convertirse en derecho consuetudinario ${ }^{(14)}$. En este caso, Anto Furundzija fue un comandante bosnio-croata que ordenó a una mujer a desnudarse delante de varios hombres y usó la violación sexual como parte de interrogatorios. Este fue acusado de graves infracciones al $\mathrm{DIH}$, entre ellas, violación sexual bajo la modalidad de tortura (Nuñez del Prado, 2012, pág. 28), y fue el primer intento de definir la violación sexual como un crimen internacional. En el fallo, la definió como un acto que implica la "penetración de la vagina o el ano de la víctima por parte del perpetrador o cualquier otro objeto usado por este; o de la boca de la víctima por el pene del perpetrador, en que la penetración debe realizarse bajo coacción o amenaza de emplear la fuerza contra la víctima o tercera persona"(15).

En la sentencia del TPIR contra Jean Paul Akayesu, dictada meses antes en setiembre de 1998, ya se había determinado que el crimen de genocidio podía perpetrarse a través de la violencia sexual. Akayesu, alcalde del municipio de Taba en la prefectura de Gitarama en Ruanda, fue declarado responsable penal del crimen de genocidio al ordenar e incitar a cometer actos de violación sexual contra mujeres tutsis y someterlas a distintos actos de naturaleza sexual como desnudos forzados, pero también fue acusado por haber cometido crímenes de lesa humanidad, dada la sistematicidad y generalidad del ataque contra la población civil. Esta sentencia fue importante porque ofreció una primera definición de la violación sexual como "la invasión física de naturaleza sexual cometida contra una persona en circunstancias que son coercitivas" ${ }^{(16)}$ y la violencia sexual como "cualquier acto de naturaleza sexual que se comete contra una persona a través de la coacción"(17).

Por su parte, en la sentencia del caso Kunarac et al, se determinó la conexión entre esclavitud y violencia sexual, así como

(13) Sentencia del Tribunal Constitucional del Expág. 2730-2006-PA/TC, de 21 de julio de 2006, fundamento 12

(14) TPIY. Case Prosecutor vs. Furundija, párr. 168. En http://www.icty.org/x/cases/furundzija/tjug/en/

(15) Sentencia del caso Fiscal con Anto Furundzija y otros, párr. 185.

(16) TPIR, Prosecutor vs. Jean Paul Akayesu, párr. 598.

(17) TPIR, Prosecutor vs. Jean Paul Akayesu, párr. 598. 
el concepto de consentimiento otorgado por la víctima. En el contexto del conflicto armado entre las fuerzas serbias y las musulmanas alrededor del pueblo de Foca, y el objetivo de eliminar a los musulmanes de dicha zona, los militares serbios instalaron un 'campamento' donde mujeres fueron tratadas como objetos de propiedad, obligadas a bailar desnudas, sometidas a continuas violaciones sexuales, por lo que los militares Dragoljub Kunarac, Radomir Kovac y Zoran Vukovic fueron hallados responsables de actos de tortura, violación sexual y en algunos casos, esclavitud sexual. Ahí se determinó que, si la violación se da en un contexto de violencia generalizada, cualquier posible consentimiento se considera inválido, debido a que las circunstancias obligan a las mujeres a acceder a dicho acto $^{(18)}$.

Este desarrollo jurisprudencial fue finalmente consolidado en el ER ${ }^{(19)}$ que crea la $\mathrm{CPI}$, donde se precisa que la violencia sexual puede ser un crimen de lesa humanidad, un crimen de guerra y bajo ciertos elementos, una forma de genocidio ${ }^{(20)}$. Reconoce, por su parte, las diversas formas de violencia sexual que pueden cometerse, como la prostitución forzada, la esclavitud sexual, el embarazo forzado, la esterilización forzada y otros. Aunque es, sin duda, un importante avance al describir la conducta típica de tales actos, garantizando mayor seguridad jurídica sobre los linderos que la delimitan, la fuente de represión no se encuentra en el tratado, sino en el derecho consuetudinario que el primero cristaliza. Tanto los estatutos de los tribunales ad hoc, como el ER, reconocen hechos que ya eran sancionados por el DPI. Como dice Salmón \& García Saavedra (2000), tales estatutos tienen el gran mérito de definir de manera sistemática los principales crímenes internacionales antes dispersos en diversos instrumentos e incluso, si nunca se alcanzara el número necesario de ratificaciones para su entrada en vigor, el texto del Estatuto "tiene como efecto la cristalización de un conjunto de normas consuetudinarias en la materia" (pág. 21).

Si bien el fenómeno de la violencia sexual fue ignorado en los TMI de Núremberg, donde sí se reconoció expresamente la prohibición de la violencia sexual en contextos de conflicto armado fue en la Ley 10 del Consejo de Control para Alemania que rigió los procedimientos contra criminales de guerra de los países europeos del Eje, juzgados por tribunales alemanes (Odio Benito, 1996, pág. 271). Según afirma Nuñez del Prado (2012), "no procesaron los delitos de violación sexual [en Núremberg] como tales, pero la subsunción dentro de otros tipos penales [otros actos inhumanos] sirvió para esclarecer que la violación sexual era un acto penado internacionalmente mucho antes de ser reconocido de manera explícita" (pág. 24).

En lo que respecta a la CPI, Jean-Pierre Bemba, comandante del Movimiento de Liberación del Congo (MLC) -grupo armado que protagonizó un CANI en la República Centroafricana del año 2002 al 2003 contra las Fuerzas Armadas Centroafricanas-, fue declarado responsable penal en 2016, entre otros, del crimen de guerra por la violación a mujeres y hombres por parte de las tropas bajo su mando. Fue la primera vez en la que se aplicó la responsabilidad de mando o de superior jerárquico del ER (Canosa \& Ospina, 2017, pág. 59) al determinar que los crímenes fueron "el resultado de la incapacidad del señor Bemba de ejercer un control adecuado", quien "a pesar del conocimiento de estos crímenes, de ser la máxima autoridad del MLC en la República Centroafricana, y de contar con los medios para ejercer dicha autoridad, el Sr. Bemba en repetidas ocasiones no tomó medidas reales y adecuadas para prevenir y reprimir los crímenes y someter estos asuntos a las autoridades competentes"(21). Tenía una posición de mando y un control efectivo sobre el plano político y militar del MLC, y conocía

(18) Sentencia Prosecutor vs. Kunarac, Kovac y Vukovic. IT-96-23-T \& IT-96-23/1-T, 22 de febrero de 2001, párr. 130.

(19) El valor del ER también se da a nivel procesal, con las Reglas de Procedimiento y Prueba (RPP) que establecen entre otras cosas, que "el consentimiento no podrá inferirse de ninguna palabra o conducta de la víctima cuando la fuerza, amenaza de la fuerza, coacción o el aprovechamiento de un entorno coercitivo hayan disminuido su capacidad para dar un consentimiento voluntario y libre" (art.70a), que la "credibilidad, la honorabilidad o la disponibilidad sexual de la víctima o de un testigo no podrán inferirse de la naturaleza sexual del comportamiento anterior o posterior de la víctima o deun testigo" (art.70d) y, que "no se admitirán pruebas del consentimiento sexual anterior o ulterior de la víctima o de un testigo" (art. 71).

(20) El artículo 145 d) de la Plataforma de Acción de Beijing de 1995 recomendó a los Estados: "Reafirmar que la violación en el curso de un conflicto armado constituye un crimen de guerra y, en ciertas circunstancias, puede considerarse un crimen de lesa humanidad y un acto de genocidio según se define en la Convención para la Prevención y la Sanción del Delito de Genocidio; y adoptar todas las medidas necesarias para proteger a las mujeres y a los niños contra esos actos y fortalecer los mecanismos para investigar y castigar a todos los responsables y procesar a los perpetradores". En https://www.acnur.org/fileadmin/Documentos/Publicaciones/2015/9853.pdf

(21) SCPI (2016a), Corte Penal Internacional. Sentencia dictada contra Jean-Pierre Bemba Gombo, Número ICC-01/05-01/08-3399, párr. 63. 
de la situación de combate, la posición de tropas y los crímenes perpetrados por estas, pero a pesar de ello, no tomó las medidas necesarias y razonables para prevenir o detener el crimen y castigar a los autores (Canosa \& Ospina, 2017, pág. 163).

Los estándares antes referidos a las distintas manifestaciones de violencia sexual en conflicto armado (como los actos típicos o el consentimiento de la víctima) y así como su calificación como crimen internacional, recogidos por la jurisprudencia de tribunales penales internacionales -sean los ad hoc o la CPI- constituyen una fuente de derecho importante del DPI, que debe ser tomado en cuenta por los tribunales nacionales para la interpretación del delito de violación sexual ocurrido en el contexto de, y con conexión, al CANI entre 1980 y 2000, y los efectos que dicha calificación despliegan en materia de persecución penal (no prescripción, no amnistía, etc.).

\subsection{Derecho Internacional de los Derechos Humanos (DIDH)} La interpretación de los tribunales ad hoc bajo el DPI de la violación sexual ha sido también respaldada por la jurisprudencia de la Corte IDH. Así, esta define el fenómeno como "actos de naturaleza sexual que se cometen contra una persona sin su consentimiento, que además de comprender la invasión física del cuerpo humano, pueden incluir actos que no involucren penetración o incluso contacto físico alguno"(22). Esto determina que la idea que comúnmente se tiene de la violación sexual como una relación sexual sin consentimiento vía vaginal, ha sido superada. La violación sexual puede ser usada así, como un medio para intimidar, degradar, humillar, castigar o controlar a la persona que la sufre, al igual que la tortura ${ }^{(23)}$. Aquí, el uso de la violación sexual como forma de tortura ha sido considerado una transgresión del artículo 5 de la $\mathrm{CADH}$, el cual regula el derecho humano a la integridad ${ }^{(24)}$, y el derecho a no ser sometido a torturas ni a penas o tratos crueles, inhumanos o degradantes.

El impacto diferenciado en base al género ha sido reconocido además, por la Corte IDH al precisar que los actos de tortura y trato cruel son más graves cuando las víctimas son mujeres $^{(25)}$, un insumo que permite graduar el reproche penal del acto. Las inspecciones vaginales dactilares de agentes estatales contra detenidas, por ejemplo, denunciadas en el caso Penal Miguel Castro Castro vs. Perú, constituyen, a su vez, un acto de violación sexual y una modalidad de tortura. La desnudez forzada, por otro lado, constituyó igualmente una violación a la dignidad personal y una forma de violencia sexual ${ }^{(26)}$. La especial vulnerabilidad de las mujeres en contextos de conflicto armado también fue reconocida por la Corte IDH, en tanto víctimas de violencia sexual(27).

Entre las obligaciones internacionales que corresponden al Estado en materia de investigar, perseguir y sancionar estos actos se encuentran las siguientes: (i) considerar como prueba fundamental el testimonio de las víctimas de violencia sexual ${ }^{(28)}$, dada la naturaleza de un acto que ocurre comúnmente en contextos de intimidad; (ii) no restar veracidad a la declaración de la presunta víctima por falta de evidencia médica, ya que no todos los actos de violencia sexual dejan lesiones físicas o enfermedades verificables a través de un examen médico ${ }^{(29)}$; (iii) realizar una adecuada apreciación y selección de pruebas a fin de neutralizar su contaminación por afirmaciones, insinuaciones y alusiones estereotipadas que vulneren la garantía de acceso a la justicia de las mujeres ${ }^{(30)}$; (iv) tomar las acciones correspondientes para evitar la "revictimización o reexperimentación de la experiencia traumática cada vez que la víctima recuerde o declare sobre lo ocurrido"(31); (v) evaluar la declaración que

(22) Corte IDH. Caso Favela Nova Brasilia Vs. Brasil. Excepciones Preliminares, Fondo, Reparaciones y Costas. Sentencia de 16 de febrero de 2017 Serie C, número 333, párr. 246.

(23) Corte IDH, Rosendo Cantú y otra vs. México. Sentencia del 2 de agosto de 2009, párr. 117.

(24) En la sentencia de la Corte IDH, Fernández Ortega y otros vs. México, párr. 308, punto resolutivo 3, se establece que la señora Fernández fue víctima de violación por la falta de entrega de información, lo que constituye una forma de tortura. Y en el fallo de la Corte IDH, Rosenda Cantú y otros vs. México, párr. 295, punto resolutivo 3, se señala que la señora Cantú fue sometida a violación sexual por parte de militares en el marco de una interrogación donde no obtuvieron la información solicitada.

(25) Corte IDH, Penal Miguel Castro Castro vs. Perú, párr. 311.

(26) Ibid, párr. 306.

(27) Corte IDH, Las Dos Erres vs. Guatemala. Sentencia del 30 de julio de 2008.

(28) Corte IDH, Rosendo Cantú y otra vs. México. Sentencia del 2 de agosto de 2009, párr. 89.

(29) Corte IDH, Espinoza Gonzáles vs. Perú. Sentencia del 30 de noviembre, 2014, párr. 193. Cfr. Corte IDH. J. vs. Perú; sentencia de 27 de noviembre, 2013, párr. 329.

(30) Corte IDH, opág. cit, párr. 278.

(31) Corte IDH, J. vs. Perú, sentencia de 27 de noviembre, párr. 351. Cfr. Corte IDH, Fernández Ortega y otros. vs. México, párr. 196; sentencia del 15 de mayo, 2011; y Corte IDH, Rosendo Cantú y otra vs. México, sentencia del 2 de agosto de 2009; párr. 180. 
da la víctima, no desacreditándola si cambia la calificación jurídica, siempre que exista una consistencia de la descripción de los hechos ${ }^{(32)}$; y (vi) incluir la perspectiva de género en la investigación y en el proceso penal|(33). Estos criterios deberán ser tomados igualmente en cuenta por los operadores del derecho al investigar y procesar las denuncias por violencia sexual, particularmente cuando han sido perpetrados en contextos de conflicto armado, dada la vulnerabilidad de la víctima y el abuso de poder de los perpetradores.

\subsection{Derecho Penal Nacional}

Aclarados los estándares internacionales vinculantes al tema, cabe remitirse a la normativa penal nacional. Cuando estos hechos de violencia sexual ocurrieron en el CANI, como lo señalé, las conductas perpetradas se regían bajo dos Códigos Penales: 1924 y 1991. El primero sancionaba el acto en el artículo 196 con una pena "no menor de dos años, al que por violencia o grave amenaza obligara a una mujer a sufrir el acto sexual fuera del matrimonio". Y a juzgar por la ubicación del delito en el Título IV: Delitos contra las buenas costumbres y Título I: delitos contra la libertad y honor sexual, y por la doctrina, el bien jurídico se consideraba entonces, el honor sexual de la mujer. Respecto a los actos ocurridos después de 1991, este estaba regulado en el artículo 170, el cual reprimía a quien "con violencia o grave amenaza, obliga a una persona a practicar el acto sexual u otro análogo", con una pena entre 3 a 6 años ${ }^{(34)}$. A partir de esta ley, se modifica la ubicación y, por tanto, el bien jurídico a proteger: la libertad sexual de la persona.

El principio de legalidad exigía, entonces, procesar los hechos bajo tales tipos penales. La CVR, sin embargo, calificó los actos de los militares como crímenes de lesa humanidad y en relación a aquellos ejecutados por PCP-SL y el MRTA, como graves infracciones al DIH, esto es, crímenes de guerra en CANI. En la medida en que los actos formaron parte de una política estatal -u organizacional-, perpetrados de manera sistemática y/o generalizada, contra la población civil, califican como crímenes de lesa humanidad, definidos en el ER, pero reconocidos por el DPI consuetudinario desde la aprobación por la Asamblea General de la ONU de los principios de Núremberg en su Resolución 95 (I) en 1946 (35).

A la misma interpretación se puede llegar con el reconocimiento jurisprudencial que hacen los tribunales ad hoc del acto como una grave infracción del artículo 3 común de los Convenios de Ginebra, al ser calificado como método de tortura, con lo cual, constituye un crimen de guerra prohibido y sancionado igualmente por el DPI consuetudinario. Reconocerlos como crímenes internacionales despliega efectos jurídicos como la imprescriptibilidad del delito, la no amnistía, el no indulto y la posibilidad de invocar la jurisdicción universal para perseguirlos ${ }^{(36)}$. Esto permite superar la barrera del paso del tiempo al momento de investigar los hechos, pero no resuelve la aplicación de una pena desproporcional al reproche socionormativo que representan.

Si bien este delito está regulado en dos Códigos Penales diferentes en base a la fecha de su comisión, este exige ser reinterpretado a la luz de los siguientes estándares jurisprudenciales vinculantes, dado que de por medio existen varios derechos fundamentales afectados. Como se sabe, una de las razones por las que muchos hechos quedaron impunes fue, no solo, la calificación jurídica aislada de estos hechos como delitos comunes, sino la lectura que se ha hecho de la ley penal vigente por esos años. Los operadores del derecho debieron (y deben, en adelante) tener en cuenta lo siguiente al investigar y procesar estos hechos:

a) Bien Jurídico: Una interpretación teleológica del tipo penal lleva a sostener que la prohibición de esta conducta se justifica solo en tanto protección de un bien jurídico, de conformidad con el principio de lesividad. En el caso de la violación sexual, es la libre autodeterminación en el ámbito sexual de personas mayores de 14 años ${ }^{(37)}$, al margen del género al que pertenece. En supuestos donde la víctima no puede consentir, sea por minoría de

(32) Corte IDH, J. vs. Perú, sentencia de 27 de noviembre; párr. 324.

(33) Corte IDH. Caso Favela Nova Brasília vs. Brasil. Excepciones Preliminares, Fondo, Reparaciones y Costas. Sentencia de 16 de febrero de 2017. Serie C, número 333, párr. 293.

(34) Este artículo es luego modificado en 2004 con la Ley 2825 para incluir la descripción del acto sexual: "el que con violencia o grave amenaza obliga a una persona a tener acceso carnal por vía vaginal, anal o bucal o realiza otros actos análogos introduciendo objetos o partes del cuerpo por alguna de las dos primeras vías, será reprimido con pena privativa de libertad no menor de seis ni mayor de ocho años".

(35) Con ello, los 55 miembros que integraban la Asamblea General expresaban su conformidad con los conceptos generales y estructuras jurídicas del derecho penal que derivaban del Estatuto del Tribunal Militar Internacional de forma explícita o implícita.

(36) Corte IDH. Caso Barrios Altos vs. Perú. Sentencia del 14 de marzo de 2001.

(37) Sentencia del Tribunal Constitucional del 12 de setiembre, 2012. STC. 00008-2012-PI/TC. 
edad, anomalía psíquica, grave alteración de la conciencia o discapacidad psicosocial, se protege la indemnidad sexual y se sanciona la actividad sexual por sí sola.

b) Resistencia física: La víctima no tiene por qué oponer resistencia física para defenderse de la violación desde que el delito se puede cometer a través de una 'grave amenaza' que haga doblegar la voluntad de la víctima para evitar males mayores. Ello basta para probar la ausencia de consentimiento. Esto también puede verificarse por la existencia de un contexto intimidatorio o de abusos sistemáticos o continuados que llevan a la víctima a no mostrar resistencia o a mantenerse en silencio, "dada la manifiesta inutilidad de la resistencia para hacer desistir al agente, o asume tal inacción a fin de evitar un mal mayor para su integridad física"(38). Como consecuencia de ello, asimismo, es innecesario que el acto deje huellas o cicatrices de agresión en el cuerpo ${ }^{(39)}$.

c) Comportamiento sexual previo: El consentimiento de la víctima es la piedra de toque del delito. Este es expresión de la autonomía y libertad individual, y como tal, puede ser revocado por cualquier motivo, "sin que ello entrañe desventaja o perjuicio alguno, incluso solo de manera verbal, ya que no es definitivo"(40). No puede derivar i) de ninguna palabra o conducta de la víctima cuando la fuerza, la amenaza de la fuerza, la coacción o el aprovechamiento de un entorno coercitivo hayan disminuido su capacidad para dar un consentimiento voluntario y libre; ii) de ninguna palabra o conducta de la víctima cuando esta sea incapaz de dar un consentimiento libre; iii) del silencio o de la falta de resistencia de la víctima a la supuesta violencia sexual. Además, no dependerá de la credibilidad o disponibilidad sexual de la víctima o de un testigo cuando estas pretendan fundarse en comportamiento anterior o posterior, de naturaleza sexual de la víctima o un testigo ${ }^{(41)}$. Cualquier intento de obtener una prueba que busque indagar por el comportamiento sexual o social previo o posterior al delito será "constitucionalmente inadmisible cuando impliquen una intromisión irrazonable, innecesaria y desproporcionada a la vida íntima"(42).

d) La retractación de la víctima: La retractación y la no persistencia en las declaraciones de las víctimas de violación sexual no puede conllevar a un menoscabo del nivel de confianza de la sindicación. Este obstáculo se supera cuando el delito se ha perpetrado en un contexto social próximo o en el entorno familiar en tanto se verifique i) la ausencia de incredibilidad subjetiva -que no haya razones para pensar que declaró por venganza, obediencia-, ii) que se presente una mínima corroboración periférica con datos de otra procedencia; y iii) sea persistente en la incriminación ${ }^{(43)}$.

e) Perspectiva de género: El enfoque de género permite identificar las relaciones de poder generadas por la construcción social y cultural de roles, prácticas, símbolos atribuidos a hombres y a mujeres en base a diferencias biológicas, que determinan una jerarquía de valores en base a lo femenino o masculino ${ }^{(44)}$. Afirma el Tribunal Constitucional que debe ser empleada en el ámbito institucional y privado, pues "ayuda a la materialización de las medidas públicas adoptadas para lograr una igualdad real de derechos entre hombres y mujeres" $(45)$. Es vinculante a todas las entidades estatales e indispensable al analizar estos casos, pues permite entender las causas y consecuencias del fenómeno a regular y combate estereotipos de género ${ }^{(46)}$ que explican y alimentan la discriminación estructural contra las

(38) Acuerdo Plenario N 1-2011/CJ-116. Fecha: 6 de diciembre, 2011, párr. 19 y 21.

(39) Corte IDH. Caso Favela Nova Brasilia vs. Brasil Sentencia de febrero, 2017, párr. 249.Corte IDH Caso J vs. Perú. Excepción Preliminar, Fondo, Reparaciones, Costas. Sentencia de 27 de noviembre de 2013, párr. 329. "La ausencia de señales físicas no implica que no se han producido maltratos, ya que es frecuente que estos actos de violencia contra las personas no dejen marcas ni cicatrices permanentes. Lo mismo es cierto para los casos de violencia y violación sexual, en los cuales no necesariamente se verá reflejada la ocurrencia de estos en un examen médico".

(40) Corte IDH. Caso I.V. Vs. Bolivia. Excepciones Preliminares, Fondo, Reparaciones y Costas. Sentencia de 30 de noviembre de 2016. Serie C, número 32974, párr. 184.

(41) Reglas 70 y 71 de las Reglas de Procedimiento y Prueba de la Corte Penal Internacional.

(42) Acuerdo Plenario número 1-2011/CJ-116. Fecha: 6 de diciembre, 2011, párr. 34.

(43) Ibid, párr. 24

(44) La perspectiva de género se encuentra reconocida de forma explícita en la Ley 28983, Ley de Igualdad de Oportunidades entre Mujeres y Hombres, el Plan Nacional de Igualdad de Género establecido en el D. S. N. ${ }^{\circ}$ 004-2012-MIMVPÁG.

(45) STC Expág. N 01479-2018-PA/TC, párr. 9.

(46) Corte IDH. Caso I.V. Vs. Bolivia. Excepciones Preliminares, Fondo, Reparaciones y Costas. Sentencia de 30 de noviembre de 2016. Serie C, número 32974, párr. 187. 
mujeres (y disidencia sexual), que puede constituirse en una barrera en el acceso a la justicia de las víctimas.

f) Responsabilidad de los funcionarios superiores o jefes militares: De acuerdo con la CVR, la responsabilidad de tales actos no solo alcanza a los perpetradores directos, sino también a sus jefes o superiores (pág. 265). Por parte del Estado, fue una práctica generalizada y subrepticiamente tolerada, pero en ciertos casos, abiertamente permitida por los superiores inmediatos (pág. 304). Los cuestionamientos sobre el título de imputación son en relación a quienes lo permitieron. A nivel del DPI, la teoría de la responsabilidad del superior sostiene que este tiene el deber de hacer respetar las leyes de la guerra a sus subordinados y no hacerlo es un incumplimiento del deber de prevenir o detener los crímenes que sus subalternos cometían, habiendo tenido el control sobre ello. A nivel del DP nacional, desde que los delitos pueden ser activos $u$ omisivos ${ }^{(47)}$, es posible recurrir a la imputación de comisión por omisión (omisión impropia) ${ }^{(48)}$, debido a que los jefes tienen un deber de garante preconfigurado respecto de bienes jurídicos que están obligados a proteger (Theidon, 158d.C., pág. 507)(49). Ello, en base a las funciones de control interno y seguridad asignado al personal en ciertos territorios. En lo que respecta a la tipicidad subjetiva, basta probar el conocimiento del riesgo prohibido de que sus subordinados están realizando actos que el jefe está en obligación de evitar y, conscientemente, no adopta las medidas necesarias para hacerlo (Meini, 2014, pág. 227). Bajo la tesis volitiva, sería un caso de dolo eventual, donde basta probar el conocimiento del riesgo de seguir realizando una conducta que evidencia la aceptación del resultado lesivo de la violación sexual.

Es importante precisar que para los supuestos donde no sea posible identificar el elemento de 'violencia o grave amenaza', una interpretación teleológica del precepto penal vigente al momento de los hechos, es decir, cuando no incluía textualmente el medio comisivo "entorno de coacción o de cualquier otro entorno que impida a la persona dar su libre consentimiento", debe incluir cualquier medio capaz de anular el consentimiento, por tanto, poner en riesgo la libertad sexual. Como dice Silva Sánchez (2006), esta interpretación busca que, "a la vista del texto y de su contexto, la resolución judicial aparezca como una consecuencia empíricamente previsible, metodológicamente defendible y axiológicamente razonable, del enunciado emitido por el legislador" (pág. 393). Identificar la razón de ser de la ley penal y su legitimidad solo se podrá lograr a través de una interpretación teleológica que se guíe por los fines de protección penal.

Los estándares jurisprudenciales a nivel nacional antes mencionados permiten delinear así, la conducta típica investigada, utilizando los respectivos tipos penales vigentes al momento de los hechos, bajo la tesis de que el principio de legalidad así lo exige. De optar por esta vía, la calificación de crimen internacional como crimen de lesa humanidad o crimen de guerra, puede operar de manera complementaria para desplegar efectos no incriminatorios como la imprescriptibilidad, no amnistía, no indulto y aplicación de la jurisdicción universal. Esto en el caso de violencia sexual durante el CANI, solo ocurrió una vez: en Manta y Vilca. Esta alternativa, sin embargo, no tendría impacto alguno, en la determinación de la pena, que seguiría rigiéndose bajo el marco abstracto de los tipos penales vigentes cuando ocurrieron los hechos.

Esta primera alternativa si bien respeta el principio de legalidad estricta en su manifestación de nullum crimen sine poena, podría llevar a aplicar una pena no efectiva, en el caso de los delitos perpetrados bajo el CP de 1924, siempre que el agresor no ofreciere matrimonio. En el caso de delitos cometidos después de 1991, en principio, sería una pena de 3 a 6 años ${ }^{(50)}$, y una de 4 a 8 años, tras la modificación de 1994 ${ }^{(51)}$. En esa línea, sería

(47) Artículo 11: Son delitos y faltas las acciones u omisiones dolosos o culposas penadas por la ley.

(48) Artículo 13: El que omite impedir la realización del hecho punible será sancionado: 1 . Si tiene el deber jurídico de impedirlo o si crea un peligro inminente que fuera propio para producirlo. 2. Si la omisión corresponde a la realización del tipo penal mediante un hacer. La pena del omiso podrá ser atenuada.

(49) Destaca Meini que existen dos deberes de garante: 1) los preconfigurados, delimitados por el ordenamiento jurídico normalmente mediante alguna regulación legal, adscritos a un determinado cargo o función; y 2) los configurados por el propio sujeto, a medida que se relaciona en sociedad, incorporando los deberes que expresan sus actos.

(50) En 1991, se promulgó el nuevo Código Penal que establecía la siguiente definición del delito de violación: "Artículo $170^{\circ}$.- El que, con violencia o grave amenaza, obliga a una persona a practicar el acto sexual u otro análogo, será reprimido con pena privativa de libertad no menor de 3 ni mayor de 6 años. Si la violación se realiza a mano armada y por dos o más sujetos, la pena será no menor de 4 ni mayor de 12 años".

(51) El 14 de febrero de 1994, mediante la Ley 26293, se modificó el artículo 170 del Código Penal de 1991 de la siguiente manera: "Artículo 170. - El que con violencia o grave amenaza, obliga a una persona a practicar el acto sexual u otro análogo, será reprimido 
un despropósito que, pese al reconocimiento internacional de la gravedad de hechos que califican como crímenes de lesa humanidad, no se imponga una pena privativa de libertad efectiva o se establezcan penas leves (Silva \& Portal, 2017, pág. 356). Este marco de pena supone, por tanto, un desafío para el principio de proporcionalidad que exige una correspondencia entre el desvalor sociojurídico del hecho y la sanción a aplicar si se trata de graves crímenes internacionales que ponen en riesgo los bienes jurídicos individuales y colectivos más importantes de la comunidad internacional.

Asimismo, de acuerdo con la Corte IDH, cuando son graves violaciones a derechos humanos -los crímenes internacionales lo son-, la regla de proporcionalidad exige que los Estados deban "asegurar, en el ejercicio de su deber de persecución de esas graves violaciones, que las penas impuestas y su ejecución no se constituyan en factores de impunidad, tomando en cuenta varios aspectos como las características del delito y la participación y culpabilidad del acusado"(52). Se sugiere así, además de los estándares previamente reseñados, una interpretación alternativa del principio de legalidad para proceder no solo a la aplicación de una pena proporcional al desvalor social del injusto, sino también proceder al reconocimiento jurídico del mismo en función de las fuentes incriminatorias del DPI.

\section{Alternativa 2}

La interpretación alternativa del principio de legalidad surge a partir de una propuesta de armonizar este principio en el derecho internacional, que sostiene que nadie podrá ser sancionado por actos $u$ omisiones que al momento de cometerse no fueran delictivos según el "derecho nacional o internacional", así como de una aproximación material que exige que la ley deba ser un instrumento único y exclusivamente para reprimir y sancionar conductas que ponen en riesgo bienes jurídicos imprescindibles para el libre desarrollo de la persona (Yacobucci, 2005, pág. 648), de conformidad con los valores y principios de un Estado Social y Democrático de Derecho. Esta mirada requiere identificar la fuente de represión recogida en el DPI, antes que en el Código Penal nacional, pues aquella es la fuente última de prohibición y sanción de estos hechos delictivos, cuyas normas vinculan a todo individuo, por encima de lo que establezca el derecho interno (Principio II de Núremberg) y lo hacen pasible de incurrir en responsabilidad penal internacional.

El Perú como Estado Parte del PIDCP (Artículo 15) ${ }^{(53)}$, la DUDH (artículo 11)(54) y la CADH (artículo 9)(55) desde 1978, se encuentra vinculado con la definición que ofrecen del principio de legalidad donde lo que prima es el derecho como fuente de represión penal, antes que la ley positiva ${ }^{(56)}$. Esta definición también está respaldada en la regla $101^{(57)}$ de las normas consuetudinarias del DIH, aplicable a conflictos armados. Las disposiciones se aceptaron sin reservas (a diferencia de Argentina) ${ }^{(58)}$, y al ser tratados de

con pena privativa de libertad no menor de 4 ni mayor de 8 años. Si la violación se realiza a mano armada y por dos o más sujetos, la pena será no menor de 8 ni mayor de 15 años".

(52) Corte IDH Manuel Cepeda Vargas vs. Colombia. Sentencia del 26 de mayo, 2010, párr. 150.

(53) Artículo 15.1. Nadie será condenado por actos u omisiones que en el momento de cometerse no fueran delictivos según el derecho nacional o internacional. Tampoco se impondrá pena más grave que la aplicable en el momento de la comisión del delito. Si con posterioridad a la comisión del delito la ley dispone la imposición de una pena más leve, el delincuente se beneficiará de ello. / 2. Nada de lo dispuesto en este artículo se opondrá al juicio ni a la condena de una persona por actos u omisiones que, en el momento de cometerse, fueran delictivos según los principios_generales del derecho reconocidos por la comunidad internacional.

(54) Artículo 11.2. Nadie será condenado por actos u omisiones que en el momento de cometerse no fueron delictivos según el Derecho nacional o internacional. Tampoco se impondrá pena más grave que la aplicable en el momento de la comisión del delito.

(55) Artículo 9. Nadie puede ser condenado por acciones u omisiones que en el momento de cometerse no fueran delictivos según el derecho aplicable. Tampoco se puede imponer pena más grave que la aplicable en el momento de la comisión del delito. Si con posterioridad a la comisión del delito la ley dispone la imposición de una pena más leve, el delincuente se beneficiará de ello. Según el informe de la CADH comentada, la frase del artículo 9 sobre "derecho aplicable" fue interpretada por el Presidente de la Comité I en 1969 en el sentido de incluir el derecho nacional e internacional.

(56) Si bien el Estatuto de Roma recoge el principio de legalidad en su acepción 'estricta' en sus artículos 22, 23 y 24, el propósito no es determinar el contenido del principio de legalidad bajo el derecho internacional, sino delimitar la jurisdicción de los delitos sobre los que el tribunal puede pronunciarse. Tanto, que el artículo 22, inciso 3 precisa: "Nada de los dispuesto en el presente artículo afectará a la tipificación de una conducta como crimen de derecho internacional independientemente del presente Estatuto".

(57) Norma 101: Nadie puede ser acusado o condenado por una acción u omisión que no constituía delito según el derecho nacional o internacional en el momento en que se cometió. Tampoco puede imponerse una pena mayor que la que era aplicable cuando se cometió la infracción penal [CAI/CANI].

(58) "Understanding: The Argentine Government states that the application of the second part of article 15 of the International Covenant on Civil and Political Rights shall be subject to the principle laid down in article 18 of the Argentine National Constitution". En https:// treaties.un.org/Pages/ViewDetails.aspx?src=TREATY\&mtdsg_no=IV-4\&chapter=4\&lang=en\#EndDec 
derechos humanos ${ }^{(59)}$, se integran, desde entonces, al derecho interno con rango constitucional. Bajo esta tesis, el freno a la arbitrariedad no lo delimita la ley, sino el derecho nacional o internacional (y la racionalidad detrás de este).

La ausencia de un marco normativo interno que regule los crímenes de lesa humanidad o los crímenes de guerra a falta de cumplir el Estado peruano el deber de implementación normativa -cuanto menos, derivado del Estatuto de Roma- para supuestos de violencia sexual perpetrada por agentes estatales o grupos armados, no puede ser una excusa para no investigar y perseguir tales hechos como corresponde ${ }^{(60)}$. Con mayor razón, si hay obligaciones internacionales que pesan sobre el Estado peruano de investigar, perseguir y sancionar graves violaciones a los derechos humanos. Así lo han entendido los tribunales nacionales que, en su mayoría, han procesado crímenes internacionales ocurridos en el Perú, congruentes con tipos penales ordinarios. Si bien esto último no está prohibido por el derecho internacional, es un desafío para el principio de proporcionalidad porque, como ya se dijo, no refleja el real desvalor de la conducta sancionada.

Esta interpretación alternativa exige, entonces asumir que la naturaleza no autoaplicativa de las normas del DPI compartida por la doctrina mayoritaria (Montoya, 2007; Salmón, 2007) no es vinculante, y que es posible aplicar directamente los delitos recogidos en el DPI, principalmente, en base a la fuente incriminatoria de la costumbre internacional. Siendo así, como sostiene Olásolo (2013), es "irrelevante si la criminalización de la conducta se ha producido mediante el Derecho nacional o el Derecho internacional, con tal de que la misma sea constitutiva de delito en el momento de llevarse a cabo" (pág. 26). Determinar la conducta típica de una fuente de derecho no escrita es un desafío que necesita de los insumos de la jurisprudencia de tribunales penales ad hoc y sus estatutos que generan un efecto cristalizador del derecho consuetudinario.

Como dice la Sala Penal Especial de la Corte Suprema, en el control de convencionalidad del indulto dictado a favor de Alberto Fujimori, condenado por crímenes de lesa humanidad, "Ios procesamientos por delitos contra la humanidad (...) están sujetos a reglas ajenas a las habituales", por tanto, "hay reglas comunes para los delitos comunes y reglas especiales para delitos de esta naturaleza, y si no fueran suficientemente claras, el Juez debe aplicar criterios de integración llenando el vacío"(61). En estos supuestos, los mecanismos están a disposición de la judicatura que, teniendo la potestad de administrar justicia, está obligada a aplicarlos ${ }^{(62)}$.

Si la razón de ser del principio de legalidad en Derecho Penal es garantizar a los individuos la seguridad de saber cuáles son los límites de su libertad para ser advertidos de cuándo su conducta pueda ser un riesgo para terceros y así frenar, además, la arbitrariedad del poder punitivo, ¿no es exigible que el sujeto conociera que lo que está haciendo está penalmente prohibido? A nivel del sistema europeo y del universal -tribunales ad hoc- se afirma que una aproximación material de este principio/derecho, tratándose de tan graves delitos, puede garantizarse si se cumplen dos elementos: i) la accesibilidad del imputado a la norma nacional o internacional que haga punible su conducta al momento de llevarse a cabo el acto, y ii) la previsibilidad de llevar a cabo su conducta según este derecho aplicable(63).

Para lo primero, basta que el Estado haya puesto al alcance el contenido de esta. Sin embargo, incluso, si eso no se cumple, sostiene Ferdinandusse (2006) que, en la práctica, al no aceptarse como defensa el desconocimiento de la ley, en realidad, este requisito no es más que un paso en la evaluación del criterio de previsibilidad (pág. 241). De igual manera, será previsible el acto

(59) Constitución peruana de 1979: "Artículo 101. Los tratados internacionales celebrados por el Perú con otros Estados forman parte del derecho nacional. En caso de conflicto entre el tratado y la ley, prevalece el primero".

"Artículo 105.-Los preceptos contenidos en los tratados relativos a derechos humanos, tienen jerarquía constitucional. No pueden ser modificados sino por el procedimiento que rige para la reforma de la Constitución”. En http://hrlibrary.umn.edu/research/PeruConstitucion\%201979.pdf

(60) Artículo 27, Convenio de Viena sobre el Derecho de los Tratados de 1969: Una parte no podrá invocar las disposiciones de su derecho interno como justificación del incumplimiento de un tratado. Esta norma se entenderá sin perjuicio de lo dispuesto en el artículo 46 .

(61) CF. Sala Penal Nacional Del Poder Judicial. <Control de convencionalidad. Alberto Fujimori Fujimori>, número 00006-2001-2-5001-SUPE-01, pág. 35.

(62) Art.139.8 de la Constitución: "Son principios y derechos de la función jurisdiccional: 8. El principio de no dejar de administrar justicia por vacío o deficiencia de la ley. En tal caso, deben aplicarse los principios generales del derecho y el derecho consuetudinario".

(63) TEDH, Caso Kononov c. Letonia, cit, párr. 185, TEDH, Caso Korbely, C.Hungría, cit, párr. 67-71; TEDH, Caso Jorgic c. Alemania cit, párr. 101-109, TEDH Caso Streletz, Kessler y Krenz C. Alemania, cit, párr. 50. 
si se cumplen dos factores: i) es de una manifiesta ilegalidad y ii) existe una mayor exigibilidad de la conducta del funcionario. Como dice Ferdinandusse: "When defendants perform public functions, often after expert trainings, they may be held to a higher standard of conduct than the average individual"(64) (pág. 246). En el caso de los más graves crímenes internacionales, la manifiesta ilegalidad del crimen y la mayor exigibilidad en la conducta de funcionarios (en crímenes avalados por el Estado) contribuye así, a asegurar la previsibilidad (y accesibilidad) de estas conductas y con ello, el contenido material del principio de legalidad. Así, agrega que desde los juicios de Núremberg y Tokio, la comunidad internacional ha asumido la prohibición de que estos crímenes son de común conocimiento: "This assumption is strengthened by the fact that the conduct that constitutes these crimes is criminalized by all legal systems in the world (...) their prohibition can also be presumed to be known for everyone"(65) (pág. 245).

Frente a la comisión de tales delitos, la acepción rígida y continental de este principio, en virtud del cual, debe existir una ley penal previa, estricta, escrita y clara para prohibir una conducta, no solo no recibe acogida en el derecho internacional consuetudinario (Gallant, 2009; pág. 370), sino que puede, en casos como estos, constituirse en un obstáculo en el cumplimiento de obligaciones internacionales en materia de perseguir y sancionar crímenes tan execrables. Así, aplicar directamente los tipos penales recogidos en fuentes del DPI no es una vulneración al principio de legalidad si este es concebido acorde a estándares del derecho internacional igualmente vinculantes al Estado peruano, conforme a una legalidad material (Miró Quesada Gayoso, 2019).

Queda, sin embargo, la duda sobre el principio de legalidad en el extremo de la pena. La norma de comportamiento prohibida en las fuentes de derecho internacional es clara (aunque siempre sujeta a interpretaciones jurisprudenciales que delimitan sus alcances, como sucede con los tipos penales recogidos en una ley interna), pero ninguna precisa qué sanción corresponde aplicar en esos casos. Como dice Cassese (2003), "for a long time, either treaties or (more seldom) customary rules have confined themselves to prohibiting certain acts (for instance, killing prisoners of war or civilians), without however adding anything on the criminal consequences of such acts (...)"(66) (pág. 17). En otras palabras, el delito existe y se perpetró, pero toca cuestionarse cómo ha de ser sancionado por los tribunales nacionales y cómo se individualiza la responsabilidad penal nacional en la pena.

¿Qué tipo de pena (y por cuánto tiempo) ha de solicitar el fiscal o imponer el juez al momento de calificar tales hechos bajo la calificación penal del DPI? Esta fue la interrogante que se plantearon tribunales penales internacionales ad hoc al establecer el marco punitivo en sus respectivos estatutos, cuyas fuentes de derecho estaban asentadas en el derecho internacional consuetudinario. La doctrina reconoce algunas salidas. Entre ellas, pedir 'por prestado' las penas recogidas en similares tipos penales ordinarios (Ferdinandusse, 2006, pág. 252), prescindir de una pena y limitarse a certificar que esté criminalizado el hecho(67), o castigarlo con la pena más alta al ser los crímenes más graves. Esto, claro está, debe ser matizado con el principio de proporcionalidad que guarde relación con la gravedad del injusto, pero también la culpabilidad del sujeto. Como dijo la Corte IDH en el fallo de la Masacre de la Rochella vs. Colombia, "la respuesta que el Estado atribuye a la conducta ilícita del autor de la transgresión debe ser proporcional al bien jurídico afectado y a la culpabilidad con la que actuó el autor, por lo que se debe establecer en función de la diversa naturaleza y gravedad de los hechos"(68). La jurisprudencia y la experiencia comparada, en todo caso, sirven de guía para determinar los criterios de la sanción.

(64) Traducción libre: "Cuando los acusados desempeñan funciones públicas, a menudo después de capacitaciones especializadas, pueden ser sometidos a un estándar de conducta más alto que el individuo promedio".

(65) Traducción libre: "Este supuesto se ve reforzado por el hecho de que la conducta que constituye estos delitos está tipificada como delito en todos los sistemas jurídicos del mundo (...) Su prohibición también puede presumirse que todos la conozcan".

(66) Traducción libre: "Durante mucho tiempo, los tratados o (más raramente) las reglas consuetudinarias se han limitado a prohibir ciertos actos (por ejemplo, matar prisioneros de guerra o civiles), sin agregar nada a las consecuencias criminales de tales actos (... ) esto dejó solas las condiciones para su represión y castigo penal".

(67) El comentario 7 del artículo 3 del borrador del Código de Crímenes contra la Paz y Seguridad de la Humanidad de 1996 que desarrolla las penas indica lo siguiente: "it is, in any event, not necessary for an individual to know in advance the precise punishment so long as the actions constitute a crime of extreme gravity for which there will be severe punishment". [Traducción libre: "En cualquier caso, no es necesario que un individuo conozca de antemano el castigo preciso siempre que las acciones constituyan un delito de extrema gravedad por el cual habrá un castigo severo".] Véase, pág. 23. Última visita: 05.05.2019. En http://legal.un.org/ilc/texts/instruments/ english/commentaries/7_4_1996.pdf

(68) Caso Corte IDH. Masacre de la Rochella vs. Colombia. Sentencia del 11 de mayo, 2007, párr. 196. 
El hecho de que no hayan penas establecidas en el derecho internacional para estos crímenes, no impide procesarlos y salvaguardar con ello el principio de legalidad material, dado que este se respeta bastando la clara determinación jurídica de la conducta incriminada y sus elementos en las respectivas fuentes de DPI, usando el DIDH para interpretar sus alcances. EI DPI también distingue entre norma de comportamiento y norma de represión, y en este caso, la costumbre da origen a la primera (la mayoría de los Estados se abstienen de ejecutarla con la conciencia de realizar así una obligación jurídica), pero la norma de represión es una consecuencia de la norma consuetudinaria de comportamiento (Comisión Internacional de Juristas, 2014, pág. 416). Por tanto, dado que la norma de sanción deriva de la del comportamiento (el injusto), es suficiente para legitimar la represión que el DPI recoja la conducta en sus fuentes de incriminación y gradúe la pena conforme a las alternativas señaladas, el principio de proporcionalidad y culpabilidad.

\section{Conclusiones}

La violencia sexual fue un fenómeno, en ciertos casos generalizado y en otros, sistemático, usada como un arma de guerra para torturar a las mujeres más vulnerables, en contextos de abuso de poder durante el conflicto armado interno entre 1980 y 2000 en el Perú. Como ocurrió en Núremberg, es sintomático que, más de 30 años después, al día de hoy, no exista condena alguna contra los perpetradores directos y mediatos por estos crímenes internacionales. Como dice Christine Chinkin, se trata de violaciones perpetradas por todos los bandos: los amigos, enemigos, y hasta los pacificadores (1994, pág. 326). El caso peruano no fue la excepción.

La justicia nacional aún tiene el reto de superar las taras de una legislación penal que ha sido favorable a la impunidad, y que es obsoleta por sí sola para investigar, procesar y sancionar un fenómeno criminal con rostro de mujer. La persecución de actos de violencia sexual necesita orientarse bajo criterios más acordes a la naturaleza del delito. Como se ha podido evidenciar en este trabajo, los/as operadores del derecho tienen el deber de aplicar estándares nacionales e internacionales bajo una perspectiva de género, y la posibilidad de apostar por una legalidad material e internacional que responda a la gravedad de hechos que hoy siguen siendo tristemente infravalorados.

\section{Referencias bibliográficas}

Ambos, K. (2004). El Nuevo Derecho Penal Internacional. Lima, Perú: ARA Editores.

Barboza, J. (1999). International Criminal Law (Vol. 3).

Boesten, J. (2010). Analizando los regímenes de violación en la intersección entre la guerra y la paz en el Perú. Debates En Sociología, 35.
(2016). Violencia sexual en la guerra y en la paz: Género, poder y justicia posconflicto en el Perú.

Brownmiller, S. (1975). Against Our Will: Men, Women and Rape. New York: Fawcett.

Canosa, J. \& Ospina, M. C. (2017). Situación en África Central, caso del Fiscal contra Jean Pierre Bemba Gombo, Sentencia conforme al artículo 74 del ECPI, ICC-01/05- 01/08, de 21 de marzo de 2016. Anuario Iberoamericano de Derecho Internacional Penal, pág. 157-168.

Cassese, A. (2003). International Criminal Law. Oxford University Press.

Chang, R. (2011). Debate en torno a la Imprescriptibilidad de Crímenes de Guerra y de Lesa Humanidad ¿Es posible su aplicación retroactiva? Ius et Veritas. Recuperado de http:// revistas.pucpág.edu.pe/index.php/iusetveritas/ article/view/12069/12636

Chinkin, C. (1994). Rape and Sexual Abuse of Women in International Law. EJIL, 326-341.

Comisión Internacional de Juristas. (2014). Derecho Internacional y lucha contra la impunidad. Suiza.

Comisión de la Verdad y de la Reconciliación (CVR)-, C. de la V. y R. (2003). Informe Final.

Dador Tozzini, M. íJennie. (2007). Mujeres sobrevivientes víctimas de violencia sexual durante el conflicto armado interno en busca de la justicia. En Justicia y Reparación para Mujeres Víctimas de Violencia Sexual en contextos de Conflicto Armado Interno. Seminario Internacional. Recuperado de https://www.verdadyreconciliacionperu.com/admin/ files/libros/484_digitalizacion.pdf

Ferdinandusse, W. N. (2006). Direct application of international criminal law in national courts. The Hague : West Nyack, NY: TMC Asser Press ; Cambridge University Press.

Henríquez Ayin, N. \& Reynoso Rendón, C. (2006). Cuestiones de género y poder en el conflicto armado en el Perú (1. ed). San Borja, Lima, Perú: CONCYTEC.

Mantilla, J. (2006). La Comisión de la Verdad y Reconciliación en el Perú y la perspectiva de género: Principales logros y hallazgos. Revista IIDH, 43, pág.324.

Meini, I. (2014). Lecciones de Derecho PenalParte General: Teoría Jurídica del Delito. Fondo Editorial PUCPÁG.

Miró Quesada Gayoso, J. (2019). El principio de legalidad en la persecución de crímenes internacionales en Perú (Licenciatura, Pontificia Universidad Católica del Perú). Recuperado de http://tesis.pucpág.edu.pe/repositorio/bitstream/ 
handle/20.500.12404/14535/Mir\%C3\%B3\%20 Quesada_Gayoso_Principio_legalidad_ Persecuci\% $\overline{\mathrm{C}} 3 \% \mathrm{~B} 3 \mathrm{n} 1$.pdf?sequence=1\&isAllowed $=\bar{y}$ Montoya, Y. (2007). El derecho internacional y los delitos. En F. Macedo, Los Caminos de la Justicia Penal y los derechos humanos. (Primera). Lima, Perú: Idehpucp.

Nuñez del Prado, F. (2012). Definiendo la violación sexual en el derecho internacional: La contribución de los Tribunales Penales Internacionales ad hoc. Agenda Internacional 19, 30, pág. 21-44.

Odio Benito, E. (1996). El Tribunal Penal Internacional para la Ex Yugoslavia -Justicia para la Paz-. Revista IIDH., Volumen 24.

(2001). De la Violación y otras graves agresiones a la integridad sexual como crímenes sancionados por el derecho internacional humanitario (crímenes de guerra). Aportes del Tribunal Penal Internacional para la Antigua Yugoslavia. En Ensayos en honor de Fernando Volio Jiménez. (pág. 262-296).

Olásolo, H. (2013). El principio nullum crimen sin iure en Derecho Internacional Contemporáneo. Anuario iberoamericano de Derecho Internacional Penal., 1, pág. 18-42.

Pérez-León Acevedo, J. PÁG. (2009). Informe sobre el auto de apertura de instrucción dictado en el proceso judicial por violencia sexual contra mujeres en confl icto armado, seguido actualmente ante la justicia peruana. [CNDDHH DOCUMENTO DE TRABAJO No 1]. Recuperado de https://www.demus. org.pe/wp-content/uploads/2015/06/9f4_doc_auto_ manta_vilca.pdf
Salazar, C. (2016). La sangre de la aurora (2da ed.). Lima: Animal de Invierno.

Salazar Luzula, K. (2006). Género, violencia sexual y derecho penal en el período posterior al conflicto en el Perú. El legado de la verdad: La justicia penal en la transición peruana.

Salmón, E. (2007). El Derecho internacional humanitario y su relación con el derecho interno de los estados. Recuperado de http://vlex. com/source/derecho-internacional-humanitario-derecho-internoestados-4871

Salmón, E. \& García Saavedra, G. (2000). Los Tribunales Internacionales que juzgan individuos. El caso de los Tribunales Ad Hoc para la ex Yugoslavia y Ruanda y el Tribunal Penal Internacional como manifestaciones institucionales de la Subjetividad Internacional del ser humano. Derecho \& Sociedad.

Segato, R. L. (2016). La guerra contra las mujeres (1ra ed.). Madrid: Traficantes de Sueños.

Silva, C. \& Portal, D. (2017). Avances en los Estándares Jurídicos Internacionales Aplicables a casos de Violación sexual en el Conflcito Armado Interno peruano. PÁG. 356. En Género y Derecho Penal. Homenaje al Prof. Wolfgang Schöne. Instituto Pacífico S.A.C.

Silva Sánchez, J. M. (2006). Sobre la interpretación 'teleológica' en Derecho Penal. Estudios de filosofía del derecho penal, pág. 365-395.

Theidon, K. S. (2015). Ocultos a plena luz los niños nacidos de la violencia sexual en tiempos de Guerra. En Analisis político, 28, pág. 158-172.

Wiesse, PÁG., Saravia, G., \& Quispe, J. J. (2018). Cuando violar a una mujer era pan de Cada día. Lima, Perú: Instituto de Defensa Legal.

Yacobucci, G. J. (2005). La transformación de la legalidad penal como desafío del nuevo siglo. En Los Desafíos del Derecho Penal en el Siglo XXI. Libro Homenaje al Profesor Dr. Gunther Jakobs. ARA Editores. 